\title{
Pengembangan Sintaks Simulasi dalam Pembelajaran Ekonomi Berorientasi pada Pendidikan Karakter
}

\author{
Fahimul Amri'1, Ery Tri Djatmika², Hari Wahyono³ ${ }^{3}$, Sri Umi Mintarti Widjaja4 \\ 1 fahimul.amri@gmail.com \\ 1 Universitas Negeri Malang
}

\begin{tabular}{ccc} 
Submitted & Revised & Accepted \\
December 14, 2018 & June 25, 2019 & June 25, 2019 \\
& http://dx.doi.org/10.17509/jpis.v28i1.14368 & \\
\hline
\end{tabular}

\begin{abstract}
This study aims to develop syntax or simulation steps in economic learning that are oriented to character education. The method used in this study is DesignBased research (DBR). The results of the study indicate that (1) prototype or design of economic learning simulation syntax contains steps, rules, roles, activities carried out in the form of cases, determined decisions, objectives of activities and role modeling, and character values developed, (2) simulation syntax based on the assessment of experts, teachers, and students, stated is valid and feasible to be applied in learning, (3) there are still some weaknesses in the simulation syntax and implementation in the field. Recommendations are given to teachers in order to carry out economic learning using simulation.
\end{abstract}

Keywords: simulation syntax, economic learning, character education.

\begin{abstract}
ABSTRAK
Penelitian ini bertujuan untuk mengembangkan sintaks atau langkahlangkah simulasi dalam pembelajaran ekonomi yang berorientasi pada pendidikan karakter. Metode yang digunakan dalam penelitian ini adalah menggunakan pendekatan Design-Based research (DBR). Hasil penelitian menunjukkan bahwa (1) prototype atau desain sintaks simulasi pembelajaran ekonomi memuat langkah-langkah, aturan, peran, kegiatan yang dilaksanakan dalam bentuk kasus-kasus, keputusan yang ditentukan, tujuan dari kegiatan dan pemeranan simulasi, dan nilai-nilai karakter yang dikembangkan, (2) sintaks simulasi berdasarkan penilaian dari ahli, guru dan, siswa valid dan layak diterapkan dalam pembelajaran, (3) masih ada beberapa kelemahan dalam sintaks simulasi dan juga pelaksanaannya di lapangan. rekomendasi diberikan kepada guru agar dapat melaksanakan pembelajaran ekonomi dengan menggunakan simulasi.
\end{abstract}

Keywords: sintaks simulasi, pembelajaran ekonomi, pendidikan karakter.

\section{PENDAHULUAN}

Pembelajaran di sekolah menjadi bagian penting untuk mewujudkan pendidikan karakter atau pendidikan moral yang sesuai dengan tujuan pendidikan nasional Indonesia. Pembelajaran di sekolah tidak hanya untuk meningkatkan pengetahuan siswa, tetapi juga bertanggung jawab untuk mengembangkan pendidikan 
karakter atau pendidikan moral siswa [1];[2]. Peran pendidikan di sekolah dapat mengembangkan pendidikan karakter bagi siswa [3]. Dalam konteks pendidikan ekonomi, pembelajaran di sekolah penting untuk membekali siswa agar aktivitas ekonomi yang dijalankan membawa manfaat dan tidak merugikan orang lain. Proses pembelajaran ekonomi harus mampu membekali siswa agar mempunyai kepedulian, mampu bekerja sama, mempunyai kejujuran, mempunyai sikap tidak serakah dalam menjalankan aktivitas ekonomi.

Kenyataannya dalam pembelajaran yang dilaksanakan di sekolah lebih banyak berorientasi pada pencapaian kemampuan kognitif siswa, sedangkan pada aspek afektif termasuk di dalamnya pendidikan karakter masih belum secara maksimal untuk diterapkan dalam proses pembelajaran [4]. Termasuk dalam pembelajaran ekonomi yang dilaksanakan di sekolah selama ini belum maksimal dalam menanamkan nilai-nilai pendidikan (karakter atau moral ekonomi). Pembelajaran ekonomi yang dilaksanakan di sekolah justru meningkatkan perilaku ekonomi yang cenderung tidak baik. Pendidikan ekonomi yang selama ini diajarkan di sekolah memiliki efek yang dapat mendorong sikap positif terhadap keserakahan [5]. Hal yang sama juga menunjukkan bahwa pendidikan ekonomi yang dipelajari oleh siswa di sekolah dapat meningkatkan perilaku yang egois dan mementingkan diri sendiri [6];[7].

Pembelajaran ekonomi yang tidak mengajarkan nilai-nilai pendidikan (karakter atau moral ekonomi) dapat membawa efek pada aktivitas ekonomi yang dijalankan. Banyak kasus yang terjadi dalam aktivitas ekonomi membawa kerugian kepada pihak lain antara lain banyaknya katin kejujuran yang ada di sekolah tidak mampu bertahan karena mengalami kerugian. Kerugian tersebut disebabkan karena pelaku ekonomi yang ada di sekolah tidak menerapkan perilaku ekonomi yang baik. Seperti yang terjadi di Bekasi dan di Tulungangung yang menunjukkan kantin kejujuran mengalami kerugian [8]; [9]. Kantin kejujuran yang didirikan di sekolah bangkrut karena moralitas siswa yang rendah yaitu perilaku yang tidak jujur [10]; [11].

Selain itu aktivitas ekonomi yang tidak mengedepankan moral ekonomi dapat dilihat dari beberapa kejadian dalam aktivitas ekonomi diantaranya adalah produksi air zamzam dan minyak zaitun palsu [12], bahan makanan mengandung formalin seperti tahu dan ayam yang berbahaya bagi kesehatan [13]; [14], dan menjual kikil busuk dan berbelatung [15]. Bahkan dalam skala yang lebih luas krisis pada tahun 2008 akibat keserakahan di pasar keuangan yang dilakukan oleh para eksekutif pada perusahaan besar sehingga menyebabkan resesi ekonomi di seluruh dunia [16]; [17].

Menyadari fakta tersebut, diperlukan adanya upaya untuk dapat menanamkan pendidikan karakter atau pendidikan moral dalam pembelajaran ekonomi. Salah satunya adalah melalui pengembangan pembelajaran dengan menggunakan simulasi. Model simulasi dalam pembelajaran ekonomi yang dikembangkan berorientasi pada pendidikan karakter atau moral ekonomi. Pendidikan karakter atau moral ekonomi berasal dari nilai-nilai luhur yang berkembang di masyarakat Indonesia. Salah satu nilai-nilai luhur yang berasal dari sosial budaya bangsa Indonesia adalah asas kekeluargaan. 
Asas kekeluargaan menjadi dasar dalam melaksanakan perekonomian nasional, seperti yang telah tercantum dalam UUD 1945 pasal 33 ayat 1. Dalam pasal tersebut mengandung moralitas ekonomi yang berasal dari nilai luhur bangsa Indonesia [18].

\section{KAJIAN LITERATUR}

\section{Simulasi Pembelajaran}

Simulasi pembelajaran menjadi metode yang menarik dalam pembelajaran. Simulasi pembelajaran merupakan suatu serangkaian teknik dan strategi dalam pembelajaran yang melibatkan individu (siswa) dalam suatu skenario kehidupan nyata melalui permainan peran, sosiodrama, psikodrama, permainan, dan refleksi untuk mengembangkan dan memperkuat pengetahuan dan keterampilan yang dipelajari di kelas [19]. Hal yang sama bahwa simulasi pembelajaran merupakan suatu pembelajaran yang memasukkan beberapa bagian dalam dunia nyata yang didasarkan pada situasi aktual atau fenomena nyata (baik fisik maupun sosial) untuk ditirukan atau disederhanakan dan ditampilkan dalam kelas. Usaha ini dirancang untuk mereplikasi atau memperkirakan situasi dan kondisi kehidupan nyata serealistis mungkin, sehingga konsep yang dipelajari dan solusi yang dikembangkan dapat benar-benar dipraktikkan dalam dunia nyata [20];[21];[22].

Simulasi

pembelajaran menciptakan lingkungan yang membuat siswa dapat berinteraksi untuk menerapkan pengetahuan dan keterampilan praktik sebelumnya ke masalah dunia nyata, hal ini berarti simulasi memberi siswa pengalaman nyata dan membuat konsep belajar lebih bermakna. Simulasi menciptakan konteks alami yang membuat siswa mampu mengenal berbagai realitas dan masalah [23];[24]. Dengan demikian dapat dikatakan bahwa simulasi menjadi bagian yang sangat penting dalam proses pembelajaran, dan merupakan alat pembelajaran yang sangat baik yang menawarkan pengalaman langsung kepada para siswa [25];[26];[27].

Senada dengan hal tersebut bahwa simulasi adalah metode dalam pembelajaran yang mencoba menciptakan pengalaman yang realistis di lingkungan yang terkendali [28]. Dalam pelaksanaannya guru lebih peduli dalam mempelajari proses psikologis dan social, dan dibutuhkan refleksi berkelanjutan yang sesuai dengan tujuan pembelajaran [28]; [27]. Simulasi pembelajaran memfokuskan pada proses belajar siswa. Siswa diberi otonomi dan independensi yang sangat tinggi, dan lebih diberdayakan untuk mengambil keputusan dalam menyelesaikan masalah yang ada [26]; [29]; [27].

Terkait dengan pembelajaran simulasi adalah bahwa simulasi pembelajaran yang dilakukan dapat mengembangkan perilaku etis dan bertanggung jawab bagi siswa untuk mengambil keputusan dalam situasi yang kompleks secara kontekstual [29]. Selanjutnya simulasi pembelajaran yang dilaksanakan dapat meningkatkan minat dan motivasi belajar siswa; meningkatkan partisipasi aktif dan keterlibatan intensif dalam belajar; meningkatkan prestasi akademik; memberikan pengalaman belajar yang baik; meningkatkan pengembangan sifat manusia seperti menghormati teman dan peduli; meningkatkan kepercayaan diri; dan mengembangan keterampilan seperti kemampuan mengambil keputusan; dan menumbuhkan sikap yang lebih baik terhadap sekolah [30]; [21]; [31]; [27]. 
Hal yang sama juga bahwa simulasi pembelajaran yang dilakukan dapat meningkatkan kerja sama dan menciptakan keadaan sosial yang saling membantu [32]; [33]; [34]. Tidak kalah penting bahwa simulasi pembelajaran sangat menyenangkan bagi siswa [30]; [32].

\section{Pendidikan Karakter}

Pendidikan karakter menjadi sangat penting keberadaannya dalam mewujudkan manusia Indonesia yang berkualitas dan berakhlak mulia seperti yang telah tergambarkan dalam tujuan pendidikan nasional Indonesia. Saat ini menunjukkan bahwa kebijakan tentang pendidikan karakter di lembaga pendidikan telah dipahami dan ditindaklanjuti secara bertahap dan berkelajutan oleh sebagian besar instansi pendidikan di daerah, baik tingkat provinsi, kabupaten/kota maupun oleh satuan pendidikan [35].

Karakter merupakan nilai-nilai khas yang baik, yang terdapat dalam diri individu dan diwujudkan dalam bentuk perilaku, sehingga dapat mempengaruhi interaksi individu terhadap Tuhan, sesama, dan lingkungannya [36]; [37]. Karakter yang ada pada individu tidak hanya berupa kebaikan yang berguna bagi dirinya sendiri tetapi juga kebaikan untuk sesama dan lingkungan sekitarnya [38]; [39]. Dengan demikian karakter tidak hanya berhubungan dengan diri sendiri, tetapi berhubungan dengan pihak lain. Manusia yang mempunyai karakter baik menunjukkan sikap dan aktivitas yang menampakkan kebaikan untuk diri sendiri dan juga terhadap orang lain serta lingkungan yang ada disekitarnya. Karakter berkaitan dengan 3 komponen yaitu pengetahuan moral (moral knonwing) yang menunjukkan bahwa setiap individu harus mengetahui tentang nilai-nilai kebaikan, sikap moral (moral felling) yang menunjukkan adanya sikap untuk melakukan perbuatan yang baik, dan perilaku moral (moral behavior) yang menunjukkan aktivitas atau perbuatan yang baik [40].

Selanjutnya karakter yang baik dapat dikembangkan melalui pendidikan. Nilai-nilai karakter dapat diintegrasikan dalam mata pelajaran dan diterapkan dalam kegiatan pembelajaran yang dilaksanakan di sekolah, Setiap guru yang melaksanakan pembelajaran dapat mengajarkan pendidikan karakter yang dimulai dari menyusun perencanaan, melaksanakan pembelajaran, dan melakukan evaluasi [37]; [4]. Pendidikan karakter merupakan usaha yang dilakukan secara terencana dalam kehidupan sosial secara menyeluruh dalam mewujudkan pembentukan karakter peserta didik [41]. Senada dengan pendapat tersebut, bahwa pendidikan karakter merupakan suatu sistem penanaman nilai-nilai karakter yang meliputi komponen pengetahuan, kesadaran, dan tindakan, agar dapat dilaksanakan oleh setiap individu dalam kehidupan yang berhubungan dengan Tuhan Yang Maha Esa, sesama, dan lingkungannya [42];[43];[39].

Pendidikan karakter adalah upaya yang dilakukan dalam mewujudkan kebaikan untuk diri sendiri dan juga orang lain serta lingkungannya [44]. Pendidikan karakter merupakan dinamika yang menyeluruh dalam kehidupan manusia, didalamnya terdapat keterkaitan antara pribadi dengan berbagai dimensi termasuk terhadap sesama dan lingkungan sosialnya [45]. Selain itu bahwa pendidikan karakter mengajarkan kebiasaan cara berpikir dan perilaku yang dapat membantu individu untuk hidup dan bekerja sama dalam kehidupan keluarga, masyarakat, dan 
negara, sehingga keputusan yang dibuat dapat dipertanggungjawabkan [46]; [47]. Dalam konteks pendidikan ekonomi, pendidikan karakter merupakan akhlak yang terbangun dan tumbuh dalam diri pelaku ekonomi melalui proses pendidikan dan pembelajaran, kemudian diimplementasikan dalam bentuk aktivitas ekonomi yang memberikan kemanfaatan dan tidak memberikan kerugian kepada pihak lain[48].

Berdasarkan beberapa pendapat tersebut, dapat diungkapkan bahwa pendidikan karakter telah diterapkan dalam lembaga pendidikan termasuk di sekolah. Pendidikan karakter dapat di integrasikan ke dalam mata pelajaran dan dilaksanakan dalam proses pembelajaran. Setiap pendidik yang mengembangkan pendidikan karakter seharusnya merancang secara tepat agar pelaksanaanya efektif dan dapat memberikan dampak bagi perubahan pada pola pikir, sikap, dan perilaku yang baik bagi peserta didik dalam kehidupan masyarakat dan negara.

Selanjutnya dalam konteks Indonesia, pendidikan karakter yang dikembangkan seharusnya berasal dari nilai-nilai sosial budaya bangsa Indonesia. Nilai-nilai luhur bangsa Indonesia telah terkristalisasi ke dalam Pancasila. Seperti diketahui bahwa Pancasila sebagai pedoman hidup bangsa Indonesia dalam bersikap dan berperilaku. Oleh karena itu pendidikan karakter yang dikembangkan di Indonesia berdasarkan pada nilai-nilai yang berasal dari pandangan hidup atau ideologi bangsa Indonesia yaitu Pancasila [49]; [36]. Dalam konteks ini pembangunan pendidikan karakter menjadi sangat penting karena merupakan upaya untuk membina dan mewarisi nilai luhur social budaya
Indonesia yang dijiwai oleh nilai-nilai Pancasila dan UUD 1945 [50].

Nilai-nilai karakter dalam penelitian ini adalah nilai-nilai karakter yang ada dalam aktivitas ekonomi, sehingga relevan dengan mata pelajaran ekonomi. Nilai-nilai karakter dalam aktivitas ekonomi dikembangkan dari nilai-nilai social budaya yang berkembang di Indonesia, sehingga sikap dan perilaku ekonomi yang dijalankan memberikan kebaikan bagi diri sendiri, orang lain, dan lingkungannya. Oleh karena itu nilai-nilai karakter yang ada dalam penelitian ini juga sesuai dengan nilai-nilai karakter yang dikembangkan oleh [51]; [41]; [48]; [52]. Nilai-nilai karakter yang dikembangkan dalam sintaks simulasi pembelajaran ekonomi adalah kerja sama, bertanggung jawab, gotong royong saling membantu, melayani, persaingan sehat, jujur, dan kepedulian.

\section{METODE PENELITIAN}

Penelitian ini menggunakan pendekatan Design-Based research (DBR) yang didaptasi dari [51]. Penelitian ini dilakukan melalui beberapa tahapan yaitu 1) identifikasi dan analisis masalah, 2) tahap pengembangan prototype, 3) tahap uji coba dan implementasi prototype, 4) dan tahap refleksi dari prototype yang telah diujicobakan sehingga mendapatkan desain yang dapat digunakan untuk menyelesaikan masalah. Tahapan tersebut dapat digambarkan sebagai berikut: 


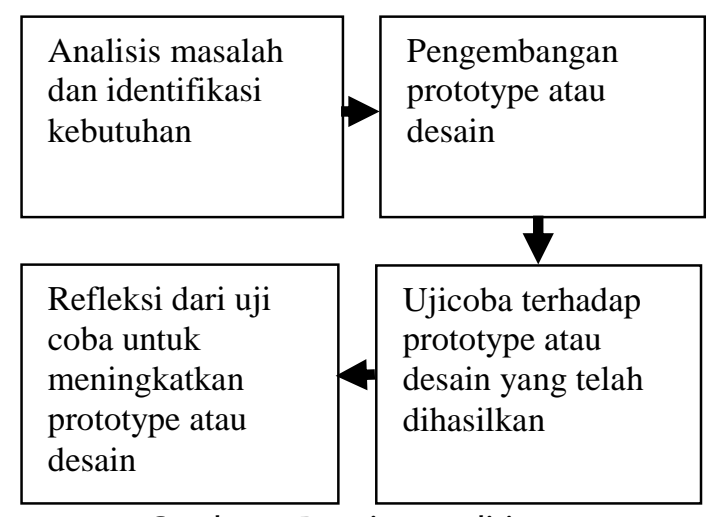

Gambar 1. Desain penelitian

Sumber: Amiel dan Reeves (2008)

Pada tahap analisis masalah dan identifikasi kebutuhan dilakukan melalui berbagai kajian terhadap pembelajaran ekonomi yang telah dilaksanakan oleh guru. Disamping itu pada tahap ini juga didukung dengan kegiatan Focus Group Discussion (FGD) dengan guru yang tergabung dalam musyawarah guru mata pelajaran ekonomi (MGMP) dan melalui survey. Pada tahap identifikasi dan analisis masalah ini dapat diketahui perlunya simulasi dalam pembelajaran ekonomi yang memuat pendidikan karakter dan moral ekonomi yang sesuai dengan nilai-nilai social budaya bangsa Indonesia.

Pada tahap pengembangan prototype atau desain simulasi dilakukan dengan menyusun langkahlangkah (sintaks) simulasi pembelajaran ekonomi yang memuat pendidikan karakter. Langkah-langkah (sintaks) simulasi pembelajaran ekonomi berisikan langkah-langkah yang harus dilakukan oleh guru dan aturan main yang dilakukan oleh siswa. Dalam aturan main simulasi yang dilaksanakan oleh siswa terdapat aturan, peran, kegiatan yang dilaksanakan dalam bentuk kasuskasus, keputusan-keputusan yang dipilih atau ditentukan, tujuan dari kegiatan dan pemeranan simulasi, dan nilai-nilai karakter yang dikembangkan.
Pada tahap pengembangan prototype atau desain juga sudah ditentukan instrument untuk menguji validitas dan efektivitas prototype yang dikembangkan. Instrument uji validitas, uji keterterapan atau kepraktisan, dan uji efektifitas dikembangkan dari [53]. Instrument uji validitas dan uji efektifitas ditentukan dengan menggunakan 4 (empat) kriteria penilaian yaitu skor $1=$ sangat tidak baik/sangat tidak setuju, skor 2 = kurang baik/kurang setuju, skor 3 = baik/setuju, dan skor $4=$ sangat baik/sangat setuju.

Pada tahap uji coba prototype atau desain yang telah dihasilkan, dilakukan uji coba kepada 2 (dua) ahli pembelajaran ekonomi untuk mendapatkan prototype atau desain yang valid, sehingga dapat diterapkan dalam proses pembelajaran. Ahli pembelajaran ekonomi diminta untuk menilai prototype atau desain tersebut dari aspek substansi dan konstruksi, apakah prototype atau desain tersebut layak atau tidak layak ketika diterapkan dalam proses pembelajaran. Apabila berdasarkan penilaian ahli terhadap Prototype atau desain tidak valid atau tidak layak, maka harus dilakukan revisi, dan apabila dinyatakan valid atau layak, maka prototype atau desain tersebut diujicobakan kepada pengguna atau praktisi (guru). Selanjutnya prototype atau desain yang sudah valid diujicobakan kepada pengguna atau guru ekonomi ekonomi dan siswa kelas $X$ IPS 2 di SMAN 3 Jombang melalui proses pembelajaran. Selain kepada guru ekonomi, siswa juga dimintai pendapat atau persepsi tentang pembelajaran simulasi yang telah dilaksanakan oleh guru.

Pada tahap refleksi, prototype atau desain yang telah dihasilkan dan diterapkan dalam proses pembelajaran direfleksikan melalui proses diskusi dan 
evaluasi dengan guru tentang kelemahan dan kelebihannya. Tahap ini dilakukan untuk menyempurnakan prototype atau desain yang telah dihasilkan, sehingga dapat digunakan untuk menyelesaikan permasalahan terutama terkait dengan pendidikan karakter dalam pembelajaran ekonomi.

\section{HASIL DAN PEMBAHASAN}

\section{Identifikasi kebutuhan dan analisis masalah}

Pada tahap ini analisis masalah dikaji dari berbagai penelitian tentang pembelajaran ekonomi yang telah dilaksanakan oleh guru. Berdasarkan kajian tersebut menunjukkan bahwa dalam pembelajaran ekonomi masih belum maksimal dalam menerapkan pendidikan karakter atau moral ekonomi. Padahal pendidikan karakter atau moral ekonomi sangat penting untuk dapat diajarkan dalam pembelajaran ekonomi. Keterbatasan dalam mengajarkan pendidikan karakter atau moral ekonomi dapat memberikan efek bagi perilaku ekonomi yang kurang baik.

Selanjutnya analisis kebutuhan terhadap sintaks simulasi pembelajaran yang berorientasi pada pendidikan karakter atau moral ekonomi juga diperoleh dari FGD dan survey. Hasil FGD dan survey yang telah dilaksanakan menunjukkan bahwa guru sudah pernah menggunakan berbagai model pembelajaran yang berpusat pada siswa. Pengalaman guru dalam menggunakan model pembelajaran yang berpusat pada siswa, dapat membuat guru lebih mudah untuk menerapkan sintaks simulasi dalam pembelajaran ekonomi yang berorientasi pada pendidikan karakter atau moral ekonomi.

Selain itu sesuai dengan program pendidikan di Indonesia tentang pengembangan pendidikan karakter, maka kebutuhan untuk mengembangkan pendidikan karakter khususnya dalam pembelajaran ekonomi sangat dibutuhkan.

Berdasarkan pada analisis masalah dan identifikasi kebutuhan tentang pengembangan sintaks simulasi pembelajaran ekonomi, maka disusun suatu prototype atau desain sintaks simulasi pembelajaran ekonomi berorientasi pada pendidikan karakter atau moral ekonomi.

\section{Pengembangan prototype atau desain}

Tahap pengembangan prototype atau desain sintaks simulasi pembelajaran ekonomi berorientasi pada pendidikan karakter atau moral ekonomi dilakukan dengan cara sebagai berikut: pertama menetapkan topic materi pelajaran ekonomi yang akan dipelajari. Pada tahap ini ditentukan tema atau topic materi ekonomi yang akan dipelajari dan disimulasikan dalam pembelajaran. Penjelasan tentang tema atau topic materi ekonomi dapat dituliskan dalam lembar tersediri. Kedua, menyusun langkah-langkah (sintaks) simulasi pembelajaran ekonomi yang memuat pendidikan karakter sesuai dengan asas kekeluargaan. Langkah-langkah (sintaks) simulasi pembelajaran ekonomi memuat prosedur kegiatan simulasi yang harus dilaksanakan oleh guru. Sintaks atau langkah-langkah simulasi dibuat sesuai dengan langkahlangkah yang telah disusun dalam perencanaan pembelajaran. Langkahlangkah simulasi dikonstruksi dari beberapa sumber tentang pembelajaran simulasi. Ketiga, Menyusun aturan main dalam simulasi. Dalam aturan main simulasi yang dilaksanakan oleh siswa terdapat aturan, peran, kegiatan yang 
dilaksanakan dalam bentuk kasus-kasus, keputusan-keputusan yang dipilih atau ditentukan, tujuan dari kegiatan dan pemeranan simulasi, dan nilai-nilai karakter yang dikembangkan.

Aturan memuat berbagai hal yang harus dilaksanakan oleh siswa ketika melaksanakan simulasi. Aturan dibuat agar pelaksanaan simulasi dapat berjalan lancar dari awal sampai akhir kegiatan. Aturan dibuat secara tegas agar dapat dilaksanakan dengan sebaikbaiknya. Peran atau pemeran juga sudah ditentukan, agar dalam pelaksanaannya, guru dapat dengan segera menentukan siswa yang menjadi pemeran, sekaligus dapat memperjelas fungsi dan tugas masing-masing peran. Selain itu dengan sudah ditentukannya pemeran dalam kegiatan simulasi dapat membuat siswa yang menjadi pemeran dapat melaksanakan peran dengan baik sesuai dengan fungsi dan tugas masingmasing.

Kegiatan yang dilaksanakan
dalam bentuk kasus juga sudah ditentukan. Kegiatan-kegiatan yang disimulasikan harus sesuai dengan tema atau topic yang telah ditentukan. Pada bagian ini disebutkan secara rinci aktivitas ekonomi yang dilakukan. Aktivitas-aktivitas ekonomi yang dijalankan memuat aktivitas ekonomi yang baik dan memuat aktivitas yang tidak baik. Tujuan dari disebutkannya aktivitas tersebut adalah memberikan gambaran bahwa dalam suatu aktivitas ekonomi ada kegiatan yang dilakukan dengan cara-cara yang dapat dibenarkan dan mengambarkan kegiatan ekonomi yang dilakukan dengan cara-cara yang tidak dapat dibenarkan (berbuat curang, keserakahan, ketidakjujuran, dan lainlain), sekaligus dapat menggambarkan bahwa kegiatan ekonomi yang dilakukan dengan cara-cara yang tidak dapat dibenarkan akan membawa dampak yang tidak baik bagi keberlanjutan aktivitas ekonomi.

$$
\text { Selanjutnya ditentukan }
$$

keputusan-keputusan yang dipilih dalam kasus yang telah ditentukan. Pada bagian ini disebutkan secara jelas keputusan-keputusan yang dipilih atau ditetapkan sesuai kasus yang dalam simulasi. Termasuk dalam bagian ini ditentukan bagaimana perilaku ekonomi yang menggunakan cara-cara yang dibenarkan maupun tidak dapat dibenarkan dilaksanakan

Selanjutnya ditetapkan tujuan dari kegiatan simulasi sesuai dengan kasus yang telah ditetapkan. Pada bagian ini ditunjukkan pengembangan sikap dan perilaku yang sesuai dengan pendidikan karakter atau moral ekonomi, dan harapannya dapat diterapkan siswa dalam aktivitas kehidupan nyata sehari-hari.

menyusun pedoman observasi aktivitas guru dan aktivitas siswa. Pedoman observasi aktivitas guru dipergunakan sebagai pedoman untuk menilai aktivitas kegiatan pembelajaran yang dilaksanakan oleh guru pada saat menggunakan simulasi. Pedoman observasi dilengkapi dengan rubric penilaian, sehingga penilaian yang diberikan sesuai dengan kondisi dan siatuasi pada saat guru melaksanakan pembelajaran. Pedoman observasi aktivitas siswa dipergunakan untuk menilai aktivitas belajar yang dilaksanakan oleh siswa. Pedoman aktivitas siswa terbagi menjadi dua yaitu pedoman aktivitas siswa dalam pembelajaran simulasi, dan pedoman penilaian sikap dan perilaku sesuai pendidikan karakter.

Menentukan instrument untuk uji validitas dan uji efektifitas prototype atau desain yang dikembangkan. Istrument ditentukan dengan 
menggunakan 4 (empat) kriteria penilaian yaitu skor 1 = sangat tidak baik/sangat tidak setuju, skor 2 = kurang baik/kurang setuju, skor 3 = baik/setuju, dan skor 4 = sangat baik/sangat setuju. (. Uji validitas diberikan kepada dua orang ahli sedangkan uji efektifitas diberikan kepada guru dan siswa. Analisis data kuantitatif untuk hasil uji validitas, uji efektifitas, dan respon siswa tersebut dihitung dengan rumus prosentase berikut:

$$
\text { nilai }=\frac{\text { skortotal / skorperolehan }}{\text { skormaksimal }} X 100
$$

Selanjutnya hasil dari perhitungan tersebut dikonversi sesuai dengan kriteria yang telah ditetapkan. Adapun kriteria tersebut nampak dalam tabel berikut:

Tabel 1. Konversi skala penilaian

\begin{tabular}{ccl}
\hline Nilai & $\begin{array}{c}\text { Skala } \\
\text { Penilaian }\end{array}$ & \multicolumn{1}{c}{ Kriteria } \\
\hline 4 & $81 \%-100 \%$ & $\begin{array}{l}\text { Sangat } \\
\text { baik/sangat layak }\end{array}$ \\
\hline 3 & $61 \%-80 \%$ & Baik/layak \\
\hline 2 & $41 \%-60 \%$ & $\begin{array}{l}\text { Kurang } \\
\text { baik/kurang layak }\end{array}$ \\
\hline 1 & $0 \%-40 \%$ & $\begin{array}{l}\text { Tidak baik/tidak } \\
\text { layak }\end{array}$ \\
\hline \multicolumn{3}{c}{ Sumber: diolah peneliti }
\end{tabular}

\section{Tahap uji coba prototype atau desain} Uji validasi ahli

Sebelum tahap uji coba ke dalam proses pembelajaran dilakukan, prototype atau desain yang telah dihasilkan harus dilakukan uji validasi agar menghasilkan prototype yang valid dan layak, sehingga dapat dipergunakan dalam proses pembelajaran. Uji validasi prototype atau desain dilakukan kepada 2 (dua) orang ahli pembelajaran ekonomi masing-masing berinisial AP dan DD. Uji validasi yang dilakukan meliputi aspek substansi dan konstruksi. Dari aspek susbtansi ditujukan untuk menilai apakah sintaks simulasi pembelajaran yang terdiri dari langkahlangkah pembelajaran dan aturan main yang telah dibuat sudah memenuhi kompetensi dan tujuan pembelajaran yang akan dicapai. Berdasarkan aspek konstruksi apakah sintaks simulasi pembelajaran yang terdiri dari langkahlangkah pembelajaran dan aturan main yang telah dibuat sudah sesuai dengan teori tentang model pembelajaran simulasi.

Instrument uji validasi terdiri dari 26 item pertanyaan dan menggunakan 4 (empat) kriteria penilaian yaitu skor $1=$ sangat tidak baik, skor 2 = kurang baik, skor 3 = baik, dan skor 4 = sangat baik. Adapun hasil penilaian kelayakan dari 2 (dua) orang ahli pembelajaran ekonomi tentang prototype atau desain sintaks simulasi pembelajaran ekonomi dapat dijelaskan dalam table berikut:

Table 2. Hasil validasi ahli

\begin{tabular}{|c|c|c|c|c|c|}
\hline No & Validator & Saran/masukan & $\begin{array}{l}\text { Total } \\
\text { skor }\end{array}$ & $\begin{array}{l}\text { Konversi } \\
\text { hasil } \\
\text { penilaian } \\
(\%)\end{array}$ & Kriteria \\
\hline 1 & Validator 1 (AP) & $\begin{array}{l}\text { 1. Pemeranan dalam } \\
\text { simulasi perlu } \\
\text { diperinci } \\
\text { 2. Alokasi waktu dalam } \\
\text { model diperjelas }\end{array}$ & 82 & 78.85 & Baik/layak \\
\hline
\end{tabular}




\begin{tabular}{|c|c|c|c|c|c|}
\hline No & Validator & Saran/masukan & $\begin{array}{l}\text { Total } \\
\text { skor }\end{array}$ & $\begin{array}{l}\text { Konversi } \\
\text { hasil } \\
\text { penilaian } \\
(\%)\end{array}$ & Kriteria \\
\hline 2 & Validator 2 (DD) & $\begin{array}{l}\text { 1. Peran dalam simulasi } \\
\text { harus dijelaskan lebih } \\
\text { terperinci } \\
\text { 2. Langkah-langkah } \\
\text { dalam simulasi juga } \\
\text { harus jelas dan rinci }\end{array}$ & 81 & 77.88 & Baik/layak \\
\hline \multicolumn{3}{|c|}{ Rerata } & 3.13 & 78.37 & Baik/layak \\
\hline
\end{tabular}

Berdasarkan hasil penilaian kelayakan dari 2 (dua) orang ahli pembelajaran ekonomi tersebut, menunjukkan bahwa prototype atau desain sintaks simulasi pembelajaran ekonomi berorientasi pada pendidikan karakter ekonomi sudah baik dan layak untuk diujicobakan dalam proses pembelajaran, meskipun ada saran dan masukan dari validator untuk perbaikan. Berdasarkan saran tersebut, sintaks simulasi dilakukan revisi sebelum uji coba diterapkan dalam proses pembelajaran.

\section{Uji coba prototype atau desain dalam proses pembelajaran}

Prototype atau desain sintaks simulasi pembelajaran ekonomi berorientasi pendidikan karakter yang telah direvisi berdasarkan saran validator, kemudian dilakukan uji coba ke dalam proses pembelajaran. Uji coba dilakukan kepada guru ekonomi yang berinisial TA dan siswa kelas X IPS 2 di SMAN 3 Jombang. Uji coba tersebut dilakukan untuk mengetahui tingkat keterterapan sintaks simulasi pembelajaran ekonomi yang dilaksanakan dalam pembelajaran. Uji keterterapan atau uji kepraktisan sintaks simulasi pembelajaran ekonomi dengan menggunakan instrument uji keterterapan yang terdiri dari 22 item pertanyaan/pernyataan dengan menggunakan 4 (empat) kriteria penilaian yaitu skor 1 = tidak baik/ tidak setuju, skor $2=$ kurang baik/kurang setuju, skor 3 = baik/setuju, dan skor $4=$ sangat baik/sangat setuju. Adapun hasil uji keterterapan dapat ditunjukkan dalam tabel berikut:

Tabel 3. Hasil penilaian uji keterterapan sintaks simulasi pembelajaran ekonomi

\begin{tabular}{llllll}
\hline No & $\begin{array}{l}\text { Praktisi } \\
\text { lguru }\end{array}$ & $\begin{array}{l}\text { To } \\
\text { tal } \\
\text { sk } \\
\text { or }\end{array}$ & $\begin{array}{l}\text { Rat } \\
\text { a- } \\
\text { rata } \\
\text { skor }\end{array}$ & $\begin{array}{l}\text { Hasil } \\
\text { penila } \\
\text { ian (\%) }\end{array}$ & kriteria \\
\hline 1 & TA & 85 & 3.86 & 96.59 & $\begin{array}{l}\text { Sangat } \\
\text { Baik/san } \\
\text { gat } \\
\text { layak }\end{array}$ \\
& & & & & \\
& & & \multicolumn{4}{c}{ Sumber: data diolah peneliti } \\
tabel & 3.
\end{tabular}
menunjukkan bahwa total skor penilaian yang diberikan oleh guru sebesar 85 dengan rata-rata skor penilaian sebesar 3.86. Berdasarkan pada tabel konversi skor, diperoleh persentase sebesar 96.59\%. Hal tersebut menunjukkan bahwa sintaks simulasi pembelajaran ekonomi berdasarkan penilaian dari guru mata pelajaran ekonomi menunjukkan kriteria sangat baik atau sangat layak ketika diterapkan dalam proses pembelajaran.

Uji efektifitas sintaks simulasi berdasarkan persepsi siswa 
Uji efektifitas dilakukan kepada siswa untuk mengetahui apakah sintask simulasi pembelajaran ekonomi yang diterapkan oleh guru efektif atau tidak ketika diterapkan dalam proses pembelajaran. Oleh karena itu dalam penelitian ini juga dilakukan uji efektifitas dengan memberikan angket berisi pertanyaan/pernyataan yang berjumlah 21 item dengan menggunakan 4 (empat) criteria penilaian yaitu skor 1 = tidak baik/ tidak setuju, skor 2 = kurang baik/kurang setuju, skor 3 = baik/setuju, dan skor $4=$ sangat baik/sangat setuju). Adapun hasil dari persepsi atau tanggapan siswa tentang pembelajaran ekonomi dengan menggunakan sintask simulasi menunjukkan hasil sebagai berikut:

Tabel 4. Persepsi atau tanggapan siswa tentang sintaks simulasi pembelajaran ekonomi

\begin{tabular}{llllll}
\hline $\mathbf{N}$ & $\begin{array}{l}\text { Jumla } \\
\mathbf{~}\end{array}$ & $\begin{array}{l}\text { Tot } \\
\text { siswa } \\
\text { sko } \\
\text { r }\end{array}$ & $\begin{array}{l}\text { Rat } \\
\text { a- } \\
\text { rata } \\
\text { sko } \\
\text { r }\end{array}$ & $\begin{array}{l}\text { Hasil } \\
\text { penilai } \\
\text { an (\%) }\end{array}$ & $\begin{array}{l}\text { kriter } \\
\text { ia }\end{array}$ \\
& & & & \\
\hline 1 & $\begin{array}{l}29 \\
\text { orang }\end{array}$ & 3.24 & 80.95 & $\begin{array}{l}\text { Baik/ } \\
\text { layak }\end{array}$ \\
\hline \multicolumn{5}{c}{ Sumber: data diolah peneliti } \\
Berdasarkan & tabel
\end{tabular}

menunjukkan bahwa skor total penilaian yang diberikan oleh siswa terhadap sintaks pembelajaran ekonomi adalah sebesar 1972 dengan rata-rata skor sebesar 3.14. Berdasarkan pada konversi skor, diperoleh persentase kelayakan sebesar $80.95 \%$. Hal tersebut menunjukkan bahwa siswa menganggap sintaks simulasi yang diikuti dalam pembelajaran ekonomi dianggap layak atau baik.

Selain itu berdasarkan hasil wawancara dengan siswa, menunjukkan bahwa pembelajaran ekonomi dengan menggunakan simulasi sangat menyenangkan bagi siswa, tidak membuat bosan, dan dapat mempraktekkan situasi kegiatan ekonomi seperti keadaan yang sebenarnya. Berdasarkan penilaian yang diberikan oleh siswa tersebut, menunjukkan bahwa sintaks simulasi pembelajaran ekonomi yang berorientasi pada pendidikan karakter mempunyai criteria baik ketika diterapkan dalam proses pembelajaran.

\section{Tahap refleksi}

Berdasarkan pada tahap uji coba yang telah dilakukan, menunjukkan beberapa kelebihan dan masih terdapat kekurangan yang perlu ada perbaikan, supaya prototype atau desain secara maksimal dapat diterapkan dalam proses pembelajaran. Beberapa kelemahan yang masih ditemukan dalam sintaks simulasi pembelajaran ekonomi berorientasi pendidikan karakter adalah sebagai berikut: 1) membutuhkan alokasi waktu yang cukup panjang. Apabila jadwal pelajaran ekonomi hanya 2 x 45 menit, maka dapat menjadi kendala dalam menerapkan sintaks simulasi pembelajaran ekonomi berorientasi pendidikan karakter; 2) sintaks simulasi belum dapat mengakomodasi semua siswa untuk dapat memerankan peran yang telah ditentukan secara maksimal; 3) dalam sintaks simulasi perlu dijelaskan media yang digunakan, sehingga akan lebih mudah bagi guru dan siswa untuk mempersiapkan media pembelajaran.

Sedangkan beberapa kelebihan dalam penerapan sintaks simulasi pembelajaran ekonomi adalah 1) sintaks simulasi menunjukkan aktivitas ekonomi yang baik atau yang sesuai dengan pendidikan karakter maupun aktivitas ekonomi yang tidak baik; dan 2) sintaks simulasi menguraikan aturan main secara jelas mulai dari menentukan aturan, menentukan pemeran, adanya 
kegiatan yang dilaksanakan dalam bentuk kasus-kasus dalam aktivitas ekonomi, menentukan keputusan yang dipilih, dan adanya tujuan permainan, dan pendidikan karakter atau moral ekonomi. Adanya kejelasan aturan main dapat mempermudah guru untuk menerapkan simulasi dalam proses pembelajaran.

\section{SIMPULAN}

Sintaks simulasi pembelajaran ekonomi berorientasi pada pendidikan karakter atau moral ekonomi yang telah dihasilkan valid dan layak untuk dapat diterapkan dalam pembelajaran ekonomi. Sintaks simulasi ketika diterapkan dalam proses pembelajaran ekonomi praktis dan efektif. Sintaks simulasi pembelajaran ekonomi yang dihasilkan memuat pendidikan karakter atau moral ekonomi yang sangat penting bagi siswa sebagai bekal untuk menjalankan aktivitas ekonomi seharihari. Sintaks simulasi dalam pembelajaran ekonomi yang berorientasi pada pendidikan karakter memberikan pedoman bagi guru untuk melaksanakan pembelajaran, sehingga pembelajaran dilaksanakan mampu menghadirkan situasi kehidupan nyata dalam aktivitas ekonomi.

\section{REKOMENDASI}

Hasil dari penelitian ini memberikan rekomendasi kepada guru agar dapat melaksanakan pembelajaran ekonomi dengan menggunakan simulasi, agar siswa mengalami dan merasakan sendiri aktivitas ekonomi seperti di kehidupan nyata. Selain itu dengan diterapkannya simulasi akan menciptakan pembelajaran yang menyenangkan. Selanjutnya dalam mempersiapkan kegiatan simulasi dalam pembelajaran ekonomi, guru harus mampu menyusun sendiri langkah-langkah simulasi dengan mencantumkan nilai-nilai karakter agar dapat dijadikan petunjuk atau pedoman dalam melaksanakan pembelajaran.

Selain itu, bagi sekolah agar dapat memberikan kesempatan kepada guru untuk menggunakan berbagai model dan metode pembelajaran termasuk simulasi yang memuat pendidikan karakter, dengan cara menyediakan sarana dan prasarana yang memadai, sehingga proses pengembangan pendidikan karakter melalui berbagai model atau metode pembelajaran terus berkelanjutan.

Implikasi hasil penelitian ini adalah memudahkan guru untuk menyampaikan pesan pembelajaran terutama terkait dengan nilai-nilai pendidikan karakter atau moral ekonomi yang harus diterapkan oleh siswa dalam kehidupan mereka.

\section{DAFTAR PUSTAKA}

[1] M. Sanger and R. Osguthorpe, "Making Sense of Approaches to Moral Education," Moral Educ, vol. 34, no. 1, pp. 57-71, 2005.

[2] P. LePage, H. Akar, Y. Temli, S. Derya, N. Hasser, and I. Ivins, "Comparing teachers' views on morality and moral education, a comparative study in Turkey and the United States," Teach. Teach. Educ., vol. 27, pp. 366-375, 2011.

[3] W. Althof and M. W. Berkowitz, "Moral Education and Character Education: Their relationship and roles in citizenship education," J. Moral Educ, vol. 35, no. 4, pp. 495518, 2006.

[4] M. A. Rubei, "Integrasi pendidikan karakter dalam pembelajaran PKN untuk mengembangkan kemandirian siswa di MTs. Mathlaul Anwar 
kota Pontianak," Sos. Horiz. J. Pendidik. Sos, vol. 2, no. 2, pp. 198-212, 2015.

[5] A. Smit, "Responsible leadership development through management education: A business ethics perspective," African J. Bus. Ethics, vol. 7, no. 2, pp. 45-51, 2013.

[6] D. M. Hausman and M. S. McPherson, "Taking ethics seriously: Economics and contemporary moral philosophy," J. Econ. Lit, vol. 31, no. 2, pp. 671-731, 1993.

[7] L. Wang and J. K. Murnighan, "On greed," Acad. Manag. Ann, vol. 5, no. 1, pp. 279-316, 2011.

[8] Republika.co.id, "Kantin kejujuran di Bekasi banyak yang bangkrut," 2009. .

[9] "Kantin kejujuran Tulungagung bangkrut," News.Okezone.com, 2008. [Online]. Available: http://news.okezone.com/read/2 008/12/29/1/177767/kantin-

kejujuran-tulungagu ng-bangkrut. [Accessed: 14-Jan-2016].

[10] "Kantin kejujuran di Bekasi banyak yang bangkrut," Republika.co.id., 2009. [Online]. Available:

http://www.republika.co.id/berita /shortlink/90966. [Accessed: 14Jan-2016].

[11] "Kantin kejujuran bangkrut," Jpnn.com, 2010. [Online]. Available: ttp://www.jpnn.com/ index.php?id=63164\&mib=berita. detail. [Accessed: 14-Jan-2016].

[12] News.liputan6.com, “Tersangka pembuat air zamzam palsu terancam pasal berlapis," 2015. .

[13] "Polisi bongkar pabrik tahu berformalin di cipayung," Metro.Sindonews.com, 2015. [Online]. Available: http://metro.sindonews.com/rea d/1022510 /170/polisi-bongkarpabrik-tahu-berformalin-dicipayung-1436538971. [Accessed: 14-Jan-2016].

[14] "Sudah lima tahun rumah potong ini jual ayam formalin," Metro.Tempo.co, 2015. [Online]. Available:

http://metro.tempo.co/read/new s/2015/09/15 /064700655/sudahlima-tahun-rumah-potong-ini-jualayam-formalin. [Accessed: 14-Jan2016].

[15] "Kiriman kikil impor bau busuk dan berbelatung," Tribunnews.com, 2015. [Online]. Available: onal/2015/03/26/kiriman -kikil-impor-bau-busuk-danberbelatung. [Accessed: 14-Jan2016].

[16] P. Whitehead and P. Crawshaw, "A tale of two economies: the political and the moral in neoliberalism," Int. J. Sociol. Soc. Policy, vol. 34 , no. 1/2, pp. 19-34, 2014.

[17] J. B. Wight, Ethics in economics: An introduction to moral frame works. Stanford: Stanford University Press, 2015.

[18] E. Ruslina, Dasar perekonomian Indonesia dalam penyimpangan mandat konstitusi UUD negara tahun 1945. Yogyakarta: Total Media, 2013.

[19] and L. S. K. Betts, M. Lewis, A. Dressler, "Optimizing learning simulation to support a quinary career development model," Asia-Pacific J. Coop. Educ, vol. 10, no. 2, pp. 99-119, 2009.

[20] I. Roux and B. Steyn, "Experiential learning and critical reflection as a tool for transfer of business knowledge: An empirical case study of a start-up simulation 
intervention for Nascent Entrepreneurs," SAJEMS NS, vol. 10, no. 3, pp. 330-347, 2007.

[21] and R. M. S. Ruiz, C. Aguado, "Educational simulation in practice: A teaching experience using a flight simulato," J. Technol. Sci. Educ, vol. 4, no. 2005, pp. 181-200, 2014.

[22] N. M. Seel and P. Blumschein, "Modeling and simulation in learning and instruction: A theoretical perspective," in Model-based approaches to learning: Using systems models and simulations to improve understanding and problem solving in complex domains, P. Blumschein, W. Hung, D. Jonassen, and S. Johannes, Eds. Rotterdam: Sense Publishers, 2009, pp. 3-15.

[23] M. L. Angelini, Integration of the pedagogical models "simulation" and "flipped classroom" in teacher instruction. SAGE Open, 2016.

[24] A. M. Zapalska and D. Brozik, "A model for developing and evaluating games and simulations in business and economic," $Z b$. rad. Ekon. fak. Rij, vol. 26, no. 2, pp. 345-368, 2008.

[25] M. L. Angelini, "Integration of the pedagogical models 'simulation' and 'flipped classroom' in teacher instruction," SAGE Open, pp. 1-8, 2016.

[26] C. Antonoaie and N. Antonoaie, "Computer-based simulations," Bull. Transilv. Univ. Bra?ov, vol. 3, no. 52, pp. 169-172, 2010.

[27] A. M. Zapalska and D. Brozik, "A model for developing and evaluating games and simulations in business and economic," $Z b$. rad. Ekon. fak. Rij, vol. 26, no. 2, pp. 345-368, 2008.
[28] P. Mack, "Understanding simulation-based learning." Life Support Training Centre Singapore General Hospital, Singapore, pp. 1-21, 2009.

[29] J. M. Beckem and M. Watkins, "Bringing life to learning: Immersive experiential learning simulations for online and blended courses," J. Asynchronous Learn. Networks, vol. 16, no. 5, pp. 61-71, 2012.

[30] K. J. Klassen and K. A. Willoughby, "In-class simulation games: Assessing student learning," J. Inf. Technol. Educ., vol. 2, pp. 1-13, 2003.

[31] M. . Srinivasan, Teaching economics in India: A teacher's handbook. New Delhi: Department of Education in Social Sciences, 2005.

[32] V. Silva and G. Xexéo, "Money basket: A classroom game about the basic mechanics of the stock exchange market," Dev. Bus. Simul. Exp. Learn., vol. 44, pp. 288-289, 2017.

[33] J. S. Zapata-Tamayo and C. M. Zapata-Jaramillo, "Building Social Communities as A Foundation for Entrepreneurship: A Game-Based Approach," Dev. Bus. Simul. Exp. Learn., vol. 42, pp. 117-123, 2015.

[34] J. S. Zapata-Tamayo, C. M. ZapataJaramillo, and M. E. Betín-Montes, "Learning Business Process Improvement by Using a Game," Dev. Bus. Simul. Exp. Learn., vol. 44, pp. 210-216, 2017.

[35] D. Rasul, "Pelaksanaan pendidikan karakter, ekonomi kreatif, dan kewirausahaan dalam belajar aktif di SMK (education of character, creative economy, and entrepreneurship in active learning in SMK)," J. Pendidik. dan 
Kebud, vol. 19, no. 1, pp. 77-93, 2013.

[36] P. R. Indonesia, Kebijakan nasional pembangunan karakter bangsa tahun 2010-2025. 2010.

[37] Sutjipto,

"Rintisan pengembangan pendidikan karakter di satuan pendidikan," J. Pendidik. dan Kebud, vol. 17, no. 5, pp. 501-524, 2011.

[38] P. Dianti, "Integrasi pendidikan karakter dalam pembelajaran pendidikan kewarganegaraan untuk mengembangkan karakter siswa," JPIS, J. Pendidik. Ilmu Sos, vol. 23, no. 1, pp. 58-68, 2014.

[39] H. Gunawan, Pendidikan karakter (konsep dan implementasi). Bandung: Alfabeta, 2012.

[40] T. Lickona, "Educating for character: How our school can teach respect and responsibility." Bantam Books, New York, 1991.

[41] Dalmeri, "Pendidikan untuk pengembangan karakter (Telaah terhadap gagasan Thomas Lickona dalam educating for character)," Al-Ulum, vol. 14, no. 1, pp. 269-288, 2014.

[42] Zubaedi, Pendidikan karakter membangun perilaku positif anak bangsa. Jakarta: Kencana Prenada Media Group, 2012.

[43] Z. Aqib, Pendidikan Karakter Membangun Perilaku Positif Anak Bangsa. Bandung: CV.Yrama Widya, 2011.

[44] Zubaedi, Desain pendidikan karakter (Konsepsi dan aplikasinya dalam lembaga pendidikan). Jakarta: Kencana Prenada Media Group, 2012.

[45] Z. Aqib, "Pendidikan karakter membangun perilaku positif anak bangsa." CV.Yrama Widya, Bandung, 2011.

[46] E. Octavia and M. A. Rubei,
"Penguatan pendidikan karakter berbasis Pancasila untuk membentuk mahasiswa Prodi PPKn menjadi warga negara yang baik dan cerdas," Sos. Horiz. J. Pendidik. Sos, vol. 4, no. 1, pp. 111124, 2017.

[47] J. Arianto, "Pengaruh unit kegiatan mahasiswa (UKM) pramuka terhadap pembentukan karakter jujur mahasiswa universitas Riau," Perspekt. Pendidik. dan Kegur., vol. 8, no. 1, pp. 90-101, 2017.

[48] F. Amri, "Mengembangkan karakter dalam pembelajaran ekonomi," in Seminar Nasional Multidisiplin 2018, 2018, no. September, pp. 110-124.

[49] Kemdiknas, "Bahan pelatihan: Penguatan metodologi pembelajaran berdasarkan nilainilai budaya untuk membentuk daya saing dan karakter bangsa, pengembangan pendidikan budaya dan karakter bangsa," usat Kurikulum, Balitbang, Kemdiknas, Jakarta, 2010.

[50] P. N. B. and C. Darmawan, "Peran pemuda sebagai penerus tradisi sambatan dalam rangka pembentukan karakter gotong royong," JPIS, J. Pendidik. IImu Sos., vol. 25, no. 1, pp. 57-76, 2016.

[51] Kemdikbud, "Penguatan Pendidikan Karakter Jadi Pintu Masuk Pembenahan Pendidikan Nasional," Kemdikbud, 2017. [Online]. Available: ttps://www.kemdikbud.go.id/mai n/blog/2017/07/penguatanpendidikan-karakter-jadi-pintumasuk-pembenahan-pendidikannasional. [Accessed: 20-May2018].

[52] Y. Kusnoto, "Internalisasi nilainilai pendidikan karakter pada 
satuan pendidikan," Sos. Horiz. J.

Pendidik. Sos., vol. 4, no. 2, pp.

247-256, 2017.

[53] S. Akbar, "Instrumen perangkat pembelajaran."

Remaja

Rosdakarya, Bandung, 2013. 